\title{
Pengemasan Tepat Guna pada Benih Kedelai (Glycine max L. Merr) Selama Penyimpanan: Analisis konsepsi Steinbauer-Sadjad periode 3
}

The Intermediate Packaging Technology on Soybean (Glycine Max L. Merr.) Seed during Storage: Analysis of Steinbauer-Sadjad's Conception in The Third Period

\author{
Author(s): Nasrullah ${ }^{(1)^{*}}$; Memen Surahman ${ }^{(1)}$; Abdul Qadir ${ }^{(1)}$ \\ (1) Departemen Agronomi dan Hortikultura, Fakultas Pertanian, Institut Pertanian Bogor \\ * Corresponding author: nasrullahaet@yahoo.com
}

\begin{abstract}
ABSTRAK
Benih kedelai memiliki daya simpan yang rendah karena penurunan kualitas benih selama penyimpanan berlangsung lebih cepat dibandingkan benih tanaman lain. Kedelai setelah dipanen akan mengalami penurunan benih baik secara kualitatif maupun karena beberapa faktor eksternal. Pengadaan benih sering dilakukan beberapa saat sebelum musim tanam sehingga benih harus disimpan dengan baik agar memiliki daya tumbuh yang tinggi saat ditanam kembali. Pengemasan benih merupakan tindakan penyediaan lingkungan mikro yang optimal agar benih tidak dipengaruhi oleh faktor lingkungan selama penyimpanan. Penyimpanan benih kedelai dilakukan di Gudang Pusat Perbenihan, Leuwikopo IPB mulai April 2018 hingga Juli 2018. Penelitian ini mempelajari pengaruh jenis kemasan dalam mempertahankan umur simpan benih selama penyimpanan. Jenis kemasan tidak berpengaruh terhadap perkecambahan benih dan kadar air, tetapi berpengaruh terhadap potensi tumbuh maksimal dan bobot kering kecambah normal, menggunakan benih yang dikemas menggunakan jerigen plastik dan plastik kedap udara memiliki potensi tumbuh maksimal yang lebih tinggi dibandingkan kertas semen. dan kantong plastik selama umur simpan 4 bulan. Benih yang disimpan selama 1 tahun dalam 4 kemasan mengalami penurunan viabilitas yang drastis, meskipun disimpan pada suhu $17-19^{\circ} \mathrm{C}$ dan $\mathrm{RH} 53-$ $55 \%$.
\end{abstract}

\section{Kata Kunci:}

Benih; masa simpan; jenis kemasan; viabilitas.

\begin{abstract}
Keywords: $\quad$ Soybean seeds have low storage capacity because the deterioration of the quality of Seed; storage period;

type of packaging; viability.

ABSTRACT soybean seeds during storage takes place faster than the seeds of other plants. After harvesting, the soybean will experience a decline in seeds both qualitatively and due to several external factors. Procurement of seeds is often done sometime before the planting season so that the seeds must be stored properly so that they have high growth power when replanted. Seed packaging is an act of providing an optimal microenvironment so that the seeds are not influenced by environmental factors during storage. Soybean seed storage is carried out in the Seed Center warehouse, Leuwikopo IPB from April 2018 to July 2018. The seeds to be used are the Anjasmoro variety which was harvested in February 2018 and obtained from the UPTD BPPTPH seed producer Unit Gading, Wonosari, Yogyakarta Special Region. This study studied the effect of the type of packaging in maintaining the shelf life of seeds during storage. The type of packaging does not affect seed germination and moisture content but affects the maximum growth potential and dry weight of normal sprouts, where the seeds packed with plastic jerry cans and hermetic plastic have a higher maximum growth potential than cement paper and plastic bags as long as 4-month shelf life. The seeds stored for 1 year in 4 packs decreased drastically in viability, even though they were stored at $17-19^{\circ} \mathrm{C}$ and $\mathrm{RH} 53-55 \%$.
\end{abstract}




\section{PENDAHULUAN}

Kedelai merupakan sumber protein nabati paling popular bagi masyarakat Indonesia pada umumnya. Konsumsi utamanya dalam bentuk tempe dan tahu yang merupakan lauk pauk vital bagi masyarakat Indonesia. Bentuk lain produk kedelai adalah kecap, tauco, dan susu kedelai. Produk ini dikonsumsi oleh sebagian besar masyarakat Indonesia. Indonesia merupakan negara produsen tempe terbesar di dunia dan menjadi pasar kedelai terbesar di Asia. Pada tahun 2013 produksi kedelai hanya 779.992 ton dengan luasan panen 550.793 ha (Badan Pusat Statistik, 2014). Hal ini menunjukkan bahwa perluasan lahan pertanaman kedelai dapat memberikan dampak yang baik untuk meningkatkan produksi kedelai. Selain luas lahan, penggunaan benih bermutu, teknik budidaya, inovasi teknologi dan penangan pasca panen juga diperlukan untuk meningkatkan produktivitas kedelai. Salah satu faktor yang menentukan keberhasilan pengembangan tanaman kedelai adalah tersedianya benih bermutu dengan daya berkecambah $>80 \%$. Penyimpanan benih bertujuan untuk menjaga ketersediaan benih dan untuk mengawetkan cadangan bahan tanam dari satu musim ke musim berikutnya. Semakin berkembangnya pertanian maka penyimpanan benih diarahkan untuk dapat mempertahankan viabilitas benih sepanjang mungkin dengan mengkondisikannya pada penyimpanan yang tepat (Justice \& Bass, 2002).

Kedelai merupakan salah satu tanaman palawija yang memiliki kadar protein yang tinggi yaitu $37 \%$. Benih kedelai juga mengandung lemak cukup tinggi yaitu $16 \%$. Kandungan protein dan lemak yang tinggi menyebabkan benih kedelai cepat mengalami kemunduran, terutama jika kondisi lingkungan simpan kurang menguntungkan (Tatipata et al., 2004). Benih kedelai memiliki daya simpan yang rendah karena kemunduran mutu benih kedelai selama penyimpanan lebih cepat berlangsung dibandingkan dengan benih tanaman lain. Benih kedelai akan mengalami kemunduran karena pengaruh faktor internal benih, maupun yang disebabkan faktor eksternal. Faktor tersebut bisa faktor fisik seperti suhu dan kelembaban, faktor kimia seperti ketersediaan oksigen maupun biologi seperti bakteri, cendawan, serangga dan tikus. Pengadaan benih sering dilakukan beberapa waktu sebelum musim tanam, sehingga benih harus disimpan dengan baik agar mempunyai daya tumbuh yang tinggi saat ditanam kembali. Pengadaan benih kedelai yang tepat jumlah dan waktu sering terkendala oleh daya simpan benih yang rendah (Purwanti, 2004).

Peran utama kemasan adalah untuk melindungi bahan yang dikemas dari kerusakan dan pengaruh luar, hingga bahan tersebut digunakan sesuai dengan tujuannya (Marsh \& Bugusu, 2007). Pengemasan benih merupakan tindakan memberikan lingkungan mikro yang optimal agar benih tidak dipengaruhi oleh faktor lingkungan selama penyimpanan benih. Prinsip utama pengemasan adalah menjaga kadar air dan respirasi benih tetap rendah dan tidak dipengaruhi oleh kelembaban dan suhu di sekitarnya (Widajati et al., 2013).

Kemasan yang digunakan adalah kemasan kedap udara dan uap air agar kadar air benih tetap terjaga. Kemasan yang kedap udara akan membatasi kandungan oksigen didalamnya, sehingga hama gudang akan mati karena kekurangan oksigen, sehingga tingkat kerusakan benih pun akan menurun. Hasil penelitian Ramadhani et al. (2018) menunjukkan bahwa kemasan jeriken plastik lebih kedap udara sehingga KA benih selama penyimpanan tetap terjaga dan mampu melindungi benih dari pengaruh kelembaban udara di luar kemasan.

Tujuan dari penelitian ini adalah: mendapatkan jenis kemasan dan periode 
simpan yang dapat mempertahankan viabilitas benih kedelai selama penyimpanan, dan mempelajari pengaruh jenis kemasan terhadap pertumbuhan benih kedelai setelah penyimpanan satu tahun.

\section{METODOLOGI}

Penelitian penyimpanan benih dilakukan di gudang benih Seed Center IPB, Leuwikopo Dramaga Bogor, sejak bulan April 2018 sampai dengan bulan Juli 2018. Penelitian di lapang dilakukan di kebun percobaan IPB, Leuwikopo Dramaga Bogor, setelah benih mengalami penyimpanan yaitu pada saat penyimpanan benih sudah dilakukan perlakuan menggunakan berbagai bahan kemasan. Pengujian viabilitas serta vigor benih kedelai dilakukan di Laboratorium Ilmu dan Teknologi Benih Departemen Agronomi dan Hortikultura IPB.

Benih yang digunakan adalah benih kedelai varietas grobogan yang dipanen pada bulan Februari 2018 dan diperoleh dari produsen benih UD Sujinah, Kabupaten Grobogan, Jawa Tengah. Alat yang digunakan adalah kemasan jeriken plastik, plastik hermetik, kertas semen, karung beralas plastik dengan masingmasing ukuran $5 \mathrm{~kg}$ benih, sealer, oven, timbangan elektrik, timbangan digital, cawan petrilabel, kamera, plastik pembungkus, germinator, desikator, wadah/baki plastik, karet, gunting, vacuum sealer. Penelitian dilapang menggunakan bahan dan alat-alat standar budidaya tanaman kedelai.

Penelitian terdiri atas dua percobaan. Percobaaan pertama adalah mempelajari pengaruh jenis kemasan dalam mempertahankan daya simpan benih selama penyimpanan. Rancangan percobaan menggunakan model rancangan petak tersarang, yaitu faktor periode simpan tersarang pada jenis kemasan. Faktor pertama adalah periode simpan dengan empat taraf, yaitu 1 bulan, 2 bulan, 3 bulan dan 4 bulan. Faktor kedua yang tersarang pada jenis kemasan simpan dengan empat taraf yaitu jeriken plastik, plastik hermetik, kertas semen, dan karung beralas plastik. Terdapat 16 kombinasi perlakuan dengan 3 ulangan, sehingga terdapat 48 satuan. Masing-masing satuan percobaan terdiri dari $5 \mathrm{~kg}$ benih kedelai, sehingga total benih yang digunakan untuk penyimpanan yaitu $240 \mathrm{~kg}$ benih. Viabilitas benih selama penyimpanan diamati dengan menggunakan peubah: Daya Berkecambah (\%) dihitung berdasarkan jumlah kecambah normal pada pengamatan pertama (hari ke-5) dan kedua (hari ke-8). Kadar Air Benih (\%) dengan cara benih kedelai sebanyak 5 gram tiap perlakuan dihancurkan menggunakan mortar, kemudian dimasukkan kedalam cawan krusibel yang telah disiapkan dan ditimbang bobotnya, benih didalam cawan krusibel selanjutnya dimasukkan ke dalam oven pada suhu rendah konstan $103 \pm 2{ }^{\circ} \mathrm{C}$ selama $17 \pm 1$ jam, benih yang telah dioven dimasukkan kedalam desikator selama 30 menit, kemudian ditimbang bobotnya. Potensi Tumbuh Maksimum (\%) dihitung berdasarkan persentase keseluruhan kecambah yang tumbuh normal maupun abnormal sampai akhir pengamatan. Berat Kering Kecambah Normal (BKKN) (g) diperoleh dengan menimbang kecambah normal pada 7 HST yang telah dikeringkan di dalam oven bersuhu $60^{\circ} \mathrm{C}$ selama 72 jam.

\section{HASIL DAN PEMBAHASAN}

\section{Pengaruh Periode Simpan dan jenis kemasan Dalam Mempertahankan Viabilitas Benih Kedelai Pada Periode 3 konsepsi Steinbauer-Sadjad Selama Penyimpanan}

Hasil analisis ragam menunjukkan bahwa jenis kemasan tidak berpengaruh nyata terhadap daya berkecambah benih serta kadar air benih, tetapi memiliki pengaruh sangat nyata terhadap potensi tumbuh maksimum dan berat kering 
kecambah normal. Faktor periode simpan tidak berpengaruh nyata terhadap daya berkecambah, kadar air dan potensi tumbuh maksimum, tetapi memiliki pengaruh sangat nyata terhadap berat kering kecambah normal. Interaksi kedua perlakuan berpengaruh sangat nyata pada peubah potensi tumbuh maksimum dan berat kering kecambah normal (Tabel 1).

Benih diduga telah mengalami kemunduran setelah dipanen pada bulan
Februari dan digunakan dalam penelitian ini pada bulan April 2018. Diduga benih yang digunakan dalam penelitian ini sudah memasuki akhir periode 3 berdasarkan konsep Steinbauer-Sadjad. Menurut Dewi (2002) kondisi lingkungan salah satunya suhu di sekitar tempat penyimpanan mempengaruhi tingkat respirasi benih, sehingga suhu di sekeliling benih meningkat.

Tabel 1. Hasil analisis ragam pengaruh jenis kemasan dan periode simpan terhadap viabilitas benih kedelai

Table 1. Analysis of the influence of various types of packaging and storage period on soybean seed viability

\begin{tabular}{lccc}
\hline $\begin{array}{l}\text { Peubah } \\
\text { Treatments }\end{array}$ & $\begin{array}{c}\text { Jenis } \\
\text { Kemasan } \\
\text { Types of } \\
\text { packaging }\end{array}$ & $\begin{array}{c}\text { Periode Simpan } \\
\text { Storage period }\end{array}$ & $\begin{array}{c}\text { Interaksi } \\
\text { Interaction }\end{array}$ \\
\hline Daya berkecambah $(\%)$ & tn & tn & tn \\
Kadar air $(\%)$ & tn & tn & tn \\
Potensi tumbuh maksimum $(\%)$ & $* *$ & tn & $* *$ \\
Berat kering kecambah normal $(\mathrm{g})$ & $* *$ & $* *$ & $* *$ \\
\hline
\end{tabular}

Keterangan:

* = berbeda nyata,

$* *$ = berbeda sangat nyata

tn $=$ Tidak Nyata menurut hasil uji Signifikansi keragaman (Uji F)

Tabel 2. Daya Berkecambah (\%) Benih Kedelai (Glycine max L. Merr.) dengan beberapa jenis kemasan

Table 2. Germination Percentage of Soybean (Glycine max L. Merr.) seeds with several types of packaging

\begin{tabular}{lcccc}
\hline \multirow{2}{*}{$\begin{array}{l}\text { Jenis kemasan } \\
\text { Types of packaging }\end{array}$} & \multicolumn{4}{c}{ Periode simpan } \\
& 1 bulan & 2 bulan & 3 bulan & 4 bulan \\
& 1 month & 2 months & 3 months & 4 months \\
\hline Jeriken plastik & 54,66 & 60,00 & 58,66 & 58,66 \\
Plastik hermetic & 57,33 & 50,66 & 57,33 & 53,33 \\
Kertas semen & 46,66 & 53,33 & 65,33 & 50,66 \\
Karung beralas plastik & 57,33 & 50,66 & 58,66 & 57,33 \\
\hline
\end{tabular}

Keterangan : Angka yang diikuti huruf yang sama dalam kolom yang sama tidak berbeda nyata pada uji Duncan taraf $\alpha=0,05$ 


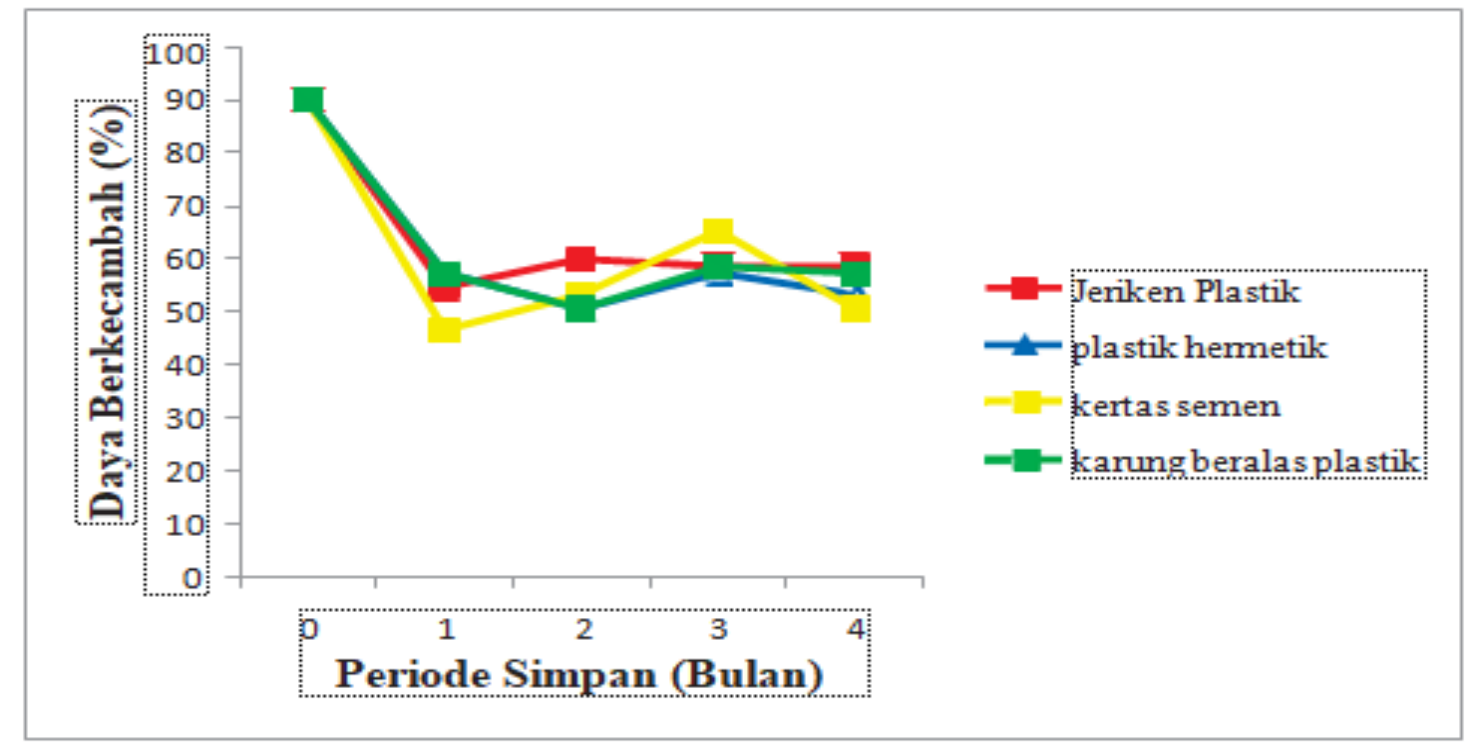

Gambar 1. Daya berkecambah benih kedelai pada penyimpanan selama 4 bulan Figure 1. Soybean seed germination on storage for 4 months

Periode viabilitas benih merupakan suatu perjalanan waktu dari seluruh hidup benih. Pada Konsepsi Steinbauer-Sadjad, viabilitas dimulai dari antesis sampai benih mati. Menurut Konsep Steinbauer-Sadjad, Sadjad (1993) mengemukakan bahwa perkembangan viabilitas benih selama periode hidup benih dibagi menjadi tiga bagian yaitu periode I, periode II, dan periode III.

Periode I merupakan periode pertumbuhan dan perkembangan benih, Periode II yaitu periode penyimpanan benih, Periode III dinamai periode kritikal dan mulai terjadi proses kemunduran vigor dan viabilitas benih. Bila benih yang sudah di Periode 3 konsepsi Steinbauer-Sadjad disimpan, maka benih mengalami laju penurunan yang tajam pada bulan 1, kemudian mengalami laju penurunan yang rendah selama 4 bulan selanjutnya. Laju penurunan daya berkecambah yang rendah selama penyimpanan 4 bulan tersebut diduga karena kadar air benih relatif konstan selama periode tersebut pada semua jenis kemasan. Hal ini diduga karena peranan ruang simpan terkontrol (suhu $17-19{ }^{\circ} \mathrm{C}$ dan $\mathrm{RH} 53-58 \%$ ) lebih besar dari pada peran kemasan yang digunakan. Ruang simpan tersebut berperan besar dalam mempertahankan respirasi benih tetap rendah.

Menurut Tatipata et al. (2004), peningkatan permeabilitas menyebabkan banyak metabolit yang keluar antara lain gula, asam amino dan lemak. Hal tersebut mengakibatkan substrat untuk respirasi berkurang sehingga energi yang dihasilkan untuk berkecambah berkurang. Menurut Purwanti (2004), kebocoran membran akibat kemunduran benih akan mempengaruhi keadaan embrio dan kotiledon yang sebagian besar terdiri atas karbohidrat, protein dan lemak yang berguna untuk pertumbuhan awal benih.

\section{Kadar Air}

Kadar air benih selalu mengalami keseimbangan dengan lingkungan atau ruang simpan. Pada kondisi ruang simpan dengan suhu $17-19{ }^{\circ} \mathrm{C}$ dan $\mathrm{RH}$ 53-58\%, kadar air keseimbangan benih sekitar 1213\% (Febriyanti \& Surahman, 2015). 
Tabel 3. Persentase Kadar Air Benih Kedelai (Glycine max L. Merr.) dengan Beberapa Jenis Kemasan

Table 3. Percentage of Moisture Content of Soybean (Glycine max L. Merr.) seeds with several types of packaging

\begin{tabular}{lcccc}
\hline \multirow{2}{*}{$\begin{array}{l}\text { Jenis kemasan } \\
\text { Types of packaging }\end{array}$} & \multicolumn{4}{c}{ Periode simpan } \\
\cline { 2 - 5 } & 1 bulan & 2 bulan & 3 bulan & 4 bulan \\
& 1 month & 2 months & 3 months & 4 months \\
\hline Jeriken plastik & 12,93 & 12,70 & 13,11 & 13,15 \\
Plastik hermetic & 13,04 & 12,86 & 13,10 & 12,72 \\
Kertas semen & 12,78 & 12,89 & 12,79 & 12,65 \\
Karung beralas plastik & 12,68 & 12,59 & 13,06 & 12,96 \\
\hline
\end{tabular}

Keterangan : Angka yang diikuti huruf yang sama dalam kolom yang sama tidak berbeda nyata pada uji Duncan taraf $\alpha=0,05$

Jika keempat jenis kemasan tersebut disimpan dalam kondisi suhu dan kelembaban kamar, diduga benih yang disimpan dalam kemasan jeriken plastik dan plastik hermetik akan memiliki mutu yang lebih baik. Berdasarkan penelitian ini benih yang disimpan selama 4 bulan memiliki daya berkecambah 50,66-58,66\% (Tabel 2) dengan kadar air 12,65-13,15\% (Tabel 3). Karena kadar airnya tidak berbeda, maka daya berkecambah juga tidak berbeda, meskipun kemasannya berbeda.

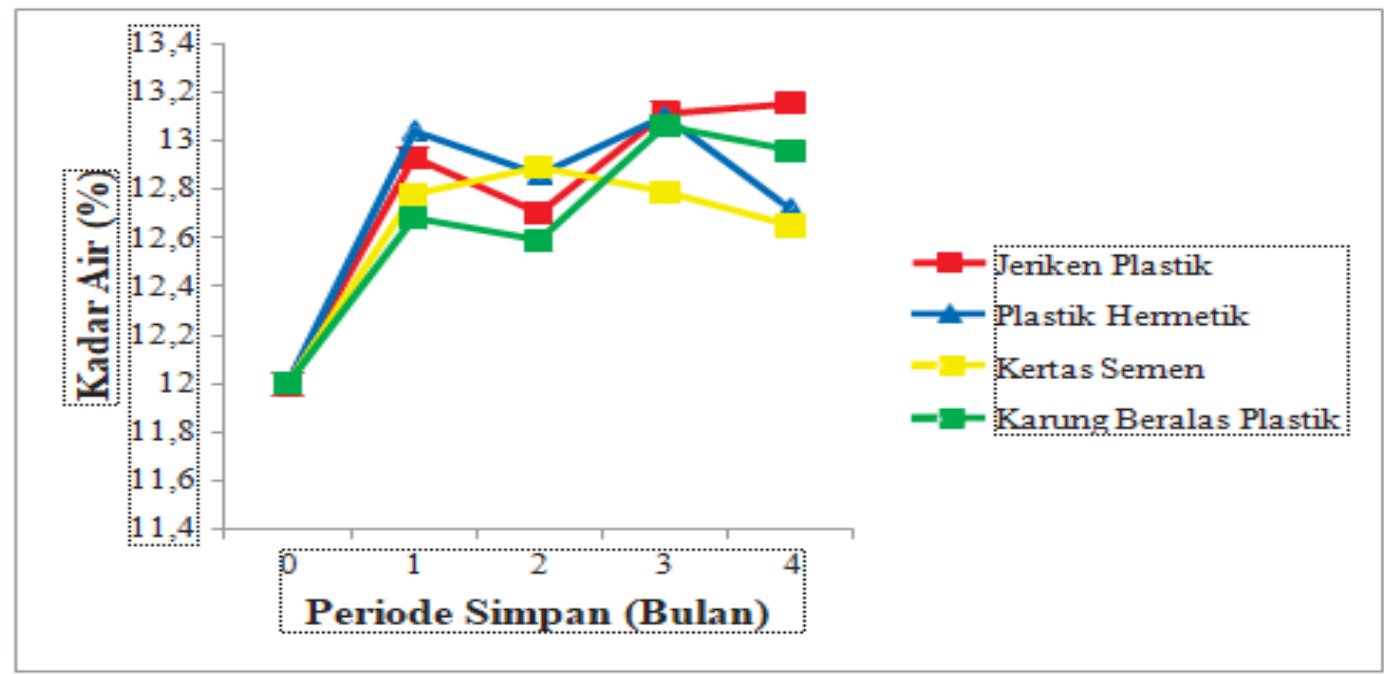

Gambar 2. Kadar air benih kedelai pada penyimpanan selama 4 bulan Figure 2. Soybean seed moisture content in storage for 4 months

Pada Gambar 2 terlihat kadar air benih kedelai dengan berbagai periode simpan tidak berbeda nyata terhadap kadar air pada semua jenis kemasan. Hal ini sesuai dengan hasil penelitian Ramadhani et al. (2018) yang menyatakan bahwa penyimpanan benih kedelai hingga 4 bulan tidak menunjukkan pengaruh yang nyata terhadap kadar air yang dikandung. Purwanti (2015) juga mengkonfirmasi bahwa pengaruh yang tidak nyata ini disebabkan oleh benih yang dikemas tidak terpengaruh oleh kondisi ruang simpan, walaupun kandungan kadar air cenderung 
konstan. Panataria, (2015) mengungkapkan bahwa lamanya penyimpanan dapat meningkatkan kadar air benih yang disimpan.

Benih yang disimpan selama enam bulan tetap melakukan aktivitas metabolisme yaitu respirasi meskipun dikemas dalam kemasan kedap, dimana aktivitas respirasi ini menghasilkan gas karbon dioksida dan uap air, berakibat pada peningkatan kadar air benih (Febriyanti \& Surahman, 2015). Asni, (2010) juga menambahkan bahwa kondisi ruang simpan, dimana benih ini bersifat higroskopis yang bisa memungkinkan terjadinya absorpsi uap air dari udara ruang simpan benih jika kadar air benih rendah, begitu pula sebaliknya.

\section{Potensi Tumbuh Maksimum}

Kombinasi perlakuan jenis kemasan dan periode simpan menunjukkan hasil yang berbeda nyata pada taraf $\alpha=0,05$ (Tabel 4). Kisaran potensi tumbuh maksimum benih selama periode simpan tersebut adalah 41,33-96,00\%. Hingga akhir periode simpan, benih dalam kemasan jeriken plastik menunjukkan potensi tumbuh maksimum yang terbaik yaitu sebsar $94,66 \%$.

Tabel 4. Potensi Tumbuh Maksimum (\%) Benih Kedelai (Glycine max L. Merr.) dengan Beberapa Jenis Kemasan

Table 4. Percentage of Maximum Growth Potential of Soybean Seeds (Glycine max L. Merr.) with several types of packaging

\begin{tabular}{lcccc}
\hline \multirow{2}{*}{ Jenis kemasan } & \multicolumn{4}{c}{ Periode simpan } \\
Types of packaging & 1 bulan & 2 bulan & 3 bulan & 4 bulan \\
& 1 month & 2 months & 3 months & 4 months \\
\cline { 2 - 5 } & $62,66 \mathrm{bc}$ & $78,66 \mathrm{ab}$ & $54,66 \mathrm{~cd}$ & $94,66 \mathrm{a}$ \\
Jeriken plastik (K1) & $94,66 \mathrm{a}$ & $96,00 \mathrm{a}$ & $86,66 \mathrm{a}$ & $85,33 \mathrm{a}$ \\
Plastik hermetic (K2) & $57,33 \mathrm{~cd}$ & $90,66 \mathrm{a}$ & $82,66 \mathrm{a}$ & $60,00 \mathrm{c}$ \\
Kertas semen (K3) & $53,33 \mathrm{~cd}$ & $41,33 \mathrm{~d}$ & $77,33 \mathrm{ab}$ & $46,66 \mathrm{~cd}$ \\
Karung beralas plastik (K4) &
\end{tabular}

Keterangan : Angka yang diikuti huruf yang sama dalam baris dan kolom yang sama tidak berbeda nyata pada uji Duncan taraf $\alpha=0,05$.

Potensi tumbuh maksimum benih kedelai memperlihatkan pola yang tidak konsisten, terutama pada periode penyimpanan 1, 2 dan 3 bulan. Penyimpanan benih pada pengamatan paling lama (4 bulan) terlihat bahwa benih yang disimpan dalam jeriken plastik dan plastik hermetic memiliki potensi tumbuh paling tinggi (Tabel 4). Meskipun potensi tumbuh maksimumnya lebih bagus, namun daya berkecambah dari benih kedelai tersebut tetap rendah. Diduga benih kedelai tersebut sudah kehabisan energi sehingga hanya mampu memunculkan radikula saja, namun tidak mampu berkecambah normal.
Perilaku benih yang tidak konsisten potensi tumbuhnya serta memiliki daya berkecambah yang rendah, merupakan ciri khas benih yang telah masuk di Periode 3 KSS, meskipun disimpan dalam kondisi pengemasan dan ruang simpan yang optimum.

\section{Berat Kering Kecambah Normal}

Pada Tabel 5 terlihat berat kering kecambah normal benih kedelai dengan berbagai periode simpan tidak berbeda nyata terhadap berat kering kecambah normal pada semua jenis kemasan. 
Tabel 5. Berat Kering Kecambah Normal (g) Benih Kedelai (Glycine max L Merr.) dengan Beberapa Jenis Kemasan

Table 5. Normal Sprout Dry Weight (g) Soybean Seed (Glycine max L Merr.) with several types of packaging

\begin{tabular}{llccc}
\hline \multirow{2}{*}{ Jenis kemasan } & \multicolumn{4}{c}{ Periode simpan } \\
Types of packaging & 1 bulan & 2 bulan & 3 bulan & 4 bulan \\
& 1 month & 2 months & 3 months & 4 months \\
\cline { 2 - 5 } & $1,01 \mathrm{~b}$ & $1,15 \mathrm{~b}$ & $1,16 \mathrm{~b}$ & $0,04 \mathrm{~cd}$ \\
Jeriken plastik & $0,74 \mathrm{bc}$ & $0,80 \mathrm{bc}$ & $0,57 \mathrm{bc}$ & $1,80 \mathrm{ab}$ \\
Plastik hermetic & $1,55 \mathrm{ab}$ & $2,21 \mathrm{a}$ & $1,42 \mathrm{ab}$ & $0,80 \mathrm{bc}$ \\
Kertas semen & $1,81 \mathrm{ab}$ & $2,42 \mathrm{a}$ & $1,29 \mathrm{~b}$ & $0,13 \mathrm{~cd}$ \\
Karung beralas plastik &
\end{tabular}

Keterangan : Angka yang diikuti huruf yang sama dalam baris dan kolom yang sama tidak berbeda nyata pada uji Duncan taraf $\alpha=0,05$.

Berat kering kecambah normal tidak berbeda nyata terhadap jenis kemasan dan periode simpan (Tabel 5). Berat kering kecambah normal tertinggi dapat dilihat pada jenis kemasan karung beralas plastik selama 2 bulan $(2,42 \mathrm{~g})$ dan berat kering kecambah normal terendah terdapat pada benih yang dikemas karung beralas selama 4 bulan $(0,14 \mathrm{~g})$. Febriyanti \& Surahman (2015) juga mendukung hasil penelitian ini benih koro (Canavalia ensiformis) yang dikemas karung terigu dan karung plastik dan disimpan pada 2, 4 dan 6 bulan di ruang kamar mengalami fluktuasi pada berat benih koro.

Berat kering kecambah normal sangat rendah, fenomena ini memperkuat Konsepsi Steinbauer-Sadjad bahwa benih yang sudah memasuki periode 3 tidak memiliki cukup energi untuk mempertahankan viabilitasnya.

\section{Pengaruh jenis kemasan yang digunakan selama penyimpanan 1 tahun terhadap pertumbuhan benih kedelai yang telah memasuki Periode 3 KSS}

Pada saat penyimpanan dilanjutkan selama 1 tahun, benih hanya mampu tumbuh sekitar 10,54-14,92\% (Tabel 6), meskipun dikemas dengan kemasan non permeabel (jeriken plastik dan plastik hermetik) ataupun poros (kertas semen dan karung plastik). Ruang simpan dengan suhu $17-19^{\circ} \mathrm{C}$ dan $\mathrm{RH} \quad 53-58 \%$ menghasilkan benih dengan kadar air keseimbangan 12-13\%. Pada kadar air keseimbangan yang optimum ini benih kehilangan $90 \%$ viabilitasnya. Hal ini membuktikan bahwa pada Periode 3 KSS benih tidak akan mampu bertahan meskipun kondisi penyimpanan optimum.

Daya tumbuh benih di lapang setelah periode simpan tersebut sangat rendah (10,54-14,92\%). Benih yang berhasil tumbuh memiliki tinggi tanaman berkisar $73,83-84,56 \mathrm{~cm}$ dengan jumlah cabang 6,76-8,36\% (Tabel 6). Jenis kemasan tidak mempengaruhi vigor bibit dilapang, terlihat dari peubah tinggi tanaman dan jumlah cabang.

Pertumbuhan tanaman kedelai sangat dipengaruhi oleh kualitas benih itu sendiri. Tanaman yang memiliki kemampuan tumbuh yang baik adalah tanaman yang berasal dari benih yang memiliki viabilitas dan vigor yang tinggi. Sutopo (2002) menyatakan bahwa vigor benih yang tinggi dicirikan antara lain oleh: (1) tahan disimpan lama (2) tahan terhadap hama dan penyakit (3) pertumbuhan yang cepat dan merata (4) mampu menghasilkan tanaman dewasa yang normal dan berproduksi baik dalam keadaan lingkungan sub-optimal. Semakin tinggi vigor maka kekuatan perkecambahan menjadi lebih baik, begitu 
pula pertumbuhan tanaman. Vigor dihubungkan dengan kekuatan kecambah, kemampuan benih untuk menghasilkan perakaran dan pucuk yang kuat pada kondisi yang tidak menguntungkan serta tahan terhadap serangan organisme (Justice \& Bass, 2002).

Tabel 6. Pengaruh faktor tunggal jenis kemasan terhadap tinggi tanaman, daya tumbuh dan jumlah cabang tanaman kedelai

Table 6. The effect of single factor type of packaging on plant height, growth power and number of branches of soybean plant

\begin{tabular}{lccc}
\hline Perlakuan & Tinggi tanaman $(\mathrm{cm})$ & Daya tumbuh $(\%)$ & $\begin{array}{c}\text { Jumlah cabang } \\
(\%)\end{array}$ \\
\hline Jeriken plastik & 79,90 & 10,54 & 7,16 \\
Plastik hermetic & 83,26 & 12,59 & 8,36 \\
Kertas semen & 84,56 & 14,92 & 6,76 \\
Karung beralas plastik & 73,83 & 11,00 & 7,03 \\
\hline
\end{tabular}

Keterangan: Angka yang diikuti huruf yang sama dalam baris dan kolom yang sama tidak berbeda nyata pada uji Duncan taraf $\alpha=0,05$.

\section{KESIMPULAN}

Jenis kemasan tidak berpengaruh terhadap daya berkecambah benih serta kadar air benih, tetapi memiliki pengaruh terhadap potensi tumbuh maksimum dan berat kering kecambah normal, menggunakan benih yang dikemas jerigen plastik dan plastik hermetik memiliki potensi tumbuh maksimum yang lebih tinggi dibanding kemasan kertas semen dan karung plastik selama periode simpan 4 bulan. Benih yang disimpan selama 1 tahun dalam 4 kemasan tersebut menurun drastis viabilitas, meskipun disimpan pada suhu $17-19{ }^{\circ} \mathrm{C}$ dan $\mathrm{RH}$ 53-55\%.

\section{DAFTAR PUSTAKA}

Asni, N. (2010). Kadar Air yang Aman Entuk Penyimpanan Benih Tanaman Pangan (Jagung, Kedelai, dan Kacang Tanah). Balai Pengkajian Teknologi Pertanian (BPTP) Jambi.

Badan Pusat Statistik. (2014). Produksi 尌 Tanaman Pangan 2014. Badan Pusat Statistik.

Dewi, M. (2002). Pengaruh Kondisi Ruang Simpan Dan Jenis Kemasan
Terhadap Viabilitas Benih Kangkung Darat (Ipomoea reptans Poir) Pada Beberapa Periode Simpan [Institut Pertanian Bogor].

Febriyanti, F., \& Surahman, M. (2015). 顽 Viabilitas Benih Koro (Canavalia ensiformis (L.) DC.) yang Disimpan pada Beberapa Jenis Kemasan dan Periode Simpan. Buletin Agrohorti, 3(1), 119-126.

Justice, O. L., \& Bass, L. N. (2002). 尌 Prinsip dan Praktek Penyimpanan Benih.

Marsh, K., \& Bugusu, B. (2007). Food 嘼 Packaging-Roles, Materials, and Environmental Issues. Journal of Food Science, 72(3), R39-R55.

Panataria, L. R. (2015). Pengaruh Kemasan 管 Simpan Terhadap Viabilitas Benih

Kedelai (Glycine max (L.) Merrill). Majalah Ilmiah Methoda, 5(1), 72 77.

Purwanti, M. D. (2015). Efektifitas 镐 Kemasan dan Suhu Ruang Simpan 
terhadap Daya Simpan Benih Kedelai (Glycine max (L.) Meirril). Planta Tropika: Journal of Agro Science, 3(1).

Purwanti, S. (2004). Kajian Suhu Ruang 尌 Simpan Terhadap Kualitas Benih Kedelai Hitam dan Kedelai Kuning. Ilmu Pertanian, 11(1), 22-31.

Ramadhani, F., Surahman, M., \& 钢 Ernawati, A. (2018). Pengaruh Jenis Kemasan terhadap Daya Simpan Benih Kedelai (Glycine max (L.) Merrill) Varietas Anjasmoro. Buletin Agrohorti, 6(1), 21-31.

Sadjad, S. (1993). Dari Benih Kepada 顽 Benih. Grasindo.

Sutopo, L. (2002). Teknologi Benih. Raja 期 Grafindo Persada.

Tatipata, A., Yudono, P., Purwantoro, A., 镀 \& Mangoendidjojo, W. (2004). Kajian Aspek Fisiologi dan Biokimia Deteriorasi Benih Kedelai Dalam Penyimpanan. Ilmu Pertanian, 11(2), 76-87.

Widajati, E., Murniati, E., Palupi, E. R., 钢 Kartika, T., Suhartanto, M. R., \& Qadir, A. (2013). Dasar Ilmu dan Teknologi Benih. IPB Press. 